\title{
Vakıfların Kurumsal İmajı Üzerinde Lider Etkisi: TEMA Vakfı ve Hayrettin Karaca
}

\author{
Ayla TOPUZ SAVAŞ*, Bahar SUVACI**
}

\begin{abstract}
Öz
Küreselleşme çağı olarak adlandırılan günümüzde, Sivil Toplum Kuruluşları (STK) toplumları şekillendiren temel etmen olarak görülmektedir. Sosyal sorumluluk faaliyetlerini temel görev olarak benimseyen vakıflar da, bir STK olarak değerlendirilmektedir. Türkiye'de, imajıyla farklılık yaratan vakıf sayısı oldukça azdır. Olumlu imaj, vakfın doğru algılanmasına topluma sağladığı faydanın anlaşılmasına ve beklentilere karşılık verebilmesine yardımcı olmaktadır. İmaj yaratmada, vakıf lideri önemli bir rol üstlenmektedir. Bu çalışmanın amacı, bir lider olarak Hayrettin Karaca ile TEMA Vakfı'nın imajı arasında bir ilişkinin varlığını belirlemek ve bir lider olarak TEMA Vakfı'nın imajı üzerindeki etkisini ölçmektir. Araştırmada kullanılan anket formunun linki katılımcıların Facebook hesaplarına gönderilmiştir ve anket formu 354 kişi tarafından cevaplanmıștır. Çalışmada amaca uygun olarak lider ile vakıf imajı arasındaki ilișkiyi belirlemek için korelasyon analizi yapılmıștır. Liderin vakıf imajı üzerindeki etkisini ölçmek için de regresyon analizi yapılmıştır. Araştırma sonuçlarına göre, lider ile kurum imajı arasında bir ilişki bulunmaktadır. Sonuçlar ayrıca liderin TEMA'nın kurum imajı üzerinde bir etkisi olduğunu da göstermektedir.
\end{abstract}

Anahtar Kelimeler: Lider, Vakıf, STK, Kurum İmajı, TEMA.

\section{Leader Impact on Foundations Corporate Image: TEMA Foundation and Hayrettin Karaca}

\begin{abstract}
Today, Non-profit Organizations (NPOs) are seen as the main factors shaping societies. Foundations that adopt social responsibility activities as basic duty are considered as an NPO. In our country, the number of foundations that make a difference with its image is quite few. The positive image helps to understand the benefits of the society to the correct perception of the foundation and to respond to expectations. The foundation leader plays an important role in image creation. The aim of this study is to determine the existence of a relationship between as a leader Hayrettin Karaca and TEMA Foundation's image and to measure the impact of TEMA Foundation on its image as a leader. The survey was used as data collection technique. The survey form was sent to the participants' Facebook accounts and 354 people answered the survey. Correlation

\author{
Özgün Araştırma Makalesi (Original Research Article) \\ Geliş/Received: 01.07.2019 \\ Kabul/Accepted: 15.05 .2020 \\ DOI: https://dx.doi.org/10.17336/igusbd.579457
}

* Dr. Öğr. Üyesi, Anadolu Üniversitesi, Eskișehir Meslek Yüksekokulu, Eskişehir, Türkiye, E-posta: atsavas@anadolu.edu.tr ORCID http://orcid.org/0000-0003-3604-5561

${ }^{* *}$ Dr. Öğr. Üyesi, Anadolu Üniversitesi, Eskişehir Meslek Yüksekokulu, Eskişehir, Türkiye, E-posta: bsuvaci@anadolu.edu.tr ORCID http://orcid.org/0000-0002-1082-0497
\end{abstract}


analysis was performed in order to determine the relationship between the leader and the foundation image. Regression analysis was also performed to measure the effect of the leader on the foundation image. According to the research results, there is a relationship between the leader and the corporate image. The results also show that the leader has an impact on TEMA's corporate image.

Keywords: Leader, Foundation, NPO, Corporate Image, TEMA.

\section{Giriş}

Küresel ekonominin gücünü giderek arttırdığı, sınırların kalktığı, iletişimin ve bilgi akışının tarihte hiç olmadığı kadar hızlandığı 21. yy'da, iletişim ve bilgi; ekonomi ve yönetimi etkilemekte ve şekillendirmektedir. Bu bilgiler, algıları şekillendirmekte kitlelerin zihninde kişiler, markalar, kurumlar hakkında imajlar oluşturmaktadır. Disiplinler arası bir kavram olan imaj; pazarlama, yönetim, reklam, halkla ilişkiler, kurumsal iletişim gibi farklı bilim dallarında tartıșılmaktadır.

21. y.y.'da, bireyler, toplumlar, kurumlar, STK'lar ve hatta ülkeler, imaj kavramını sahip olduğu değerlerin/varlıkların ayrılmaz bir parçası olarak görmektedir. İmaj sayesinde, rakiplerden daha avantajlı hale gelmek, hedef kitlenin desteğini almak daha kolaylaşabilmektedir. Ticari kurumların olduğu kadar bir sivil toplum kuruluşu olarak vakıfların da olumlu imaja sahip olmaları, imaja bağlı olarak aldıkları destekle orantılı olarak varlıklarını sürdürebilmelerinin neredeyse temel koşuludur.

Vakıflar, güçlü bir imaja sahip olarak kamuoyunun desteğini alabilir. Gelirleri genellikle elde ettikleri bağışlar olan vakıflar, bu destek sayesinde varlıklarını sürdürebilirler ve kuruluş amaçları doğrultusunda çalışabilirler. Vakıfların bu desteği alabilmek için ihtiyaç duydukları güçlü imajın oluşturulabilmesinde gerekli olan unsurlardan biri de liderdir. Diğer deyişle vakıfların sürdürülebilir olması için güçlü bir lidere ve buna bağlı olarak güçlü bir kurumsal imaja sahip olmaları önemlidir. Ancak alanyazında, vakıfların hedef kitle üzerinde kurumsal imajını ölçen ya da liderin, yönettiği vakfın kurumsal imajı üzerindeki etkisini analiz eden bir çalışmaya rastlanılmamıştır.

$\mathrm{Bu}$ çalışmanın amacl, bir vakfın güçlü bir imaja sahip olabilmesinde liderin ne düzeyde etkili olduğunu ölçmektir. Bu amaçla, bir STK olan TEMA Vakfi'nın (Türkiye Erozyonla Mücadele Ağaçlandırma ve Doğal Varlıkları Koruma Vakfi) kurucu lideri olarak Hayrettin Karaca'nın vakıf imajı üzerindeki etkisi ölçülmeye çalışılmıştır.

\section{Sivil Toplum Kuruluşu Olarak Vakıflar ve TEMA Vakfı}

STK'lar, devletin denetimi altında olmayan, kararlarını bağımsız olarak vererek toplumsal etkinliklerde bulunan bireyler topluluğu olarak (tdk.gov.tr, 2017) tanımlanmaktadır. STK'lar toplum, çevre, temizlik, sağlık, eğitim gibi pek çok alanda sorunların çözümü için gönüllü olarak faaliyet gösteren ve kar amacı gütmeyen kurumlardır.

Sivil toplumun, sosyal hayatı ve çevreyi ilgilendiren sorunların çözümüne yönelik tartışmaları ve kamusal alanlar çerçevesinde kurumlaştıracak yapılarını ise, "Vakıflardan, kültür derneklerinden ve akademilerden bağımsız medyaya, spor ve boş zaman derneklerine, tartışma kulüplerine, vatandaş forumlarına ve yurttaş inisiyatiflerinden, meslek birliklerine, siyasal partilere, sendikalara ve alternatif kurumlara dek uzanan devlet dışı ve ekonomi dışı gönüllü birliktelikler" oluşturmaktadır (Habermas, 2015, s. 33). Sivil toplumun varlığından ve gerçekliğinden bahsedilebilmesi için demokratik bir toplum gereklidir. Sivil toplum için yine devletin hukuk devleti olması yani hukukla 
sınırlanmış ve temel hak ve hürriyetleri tanıyan bir yapıyı kurmuş olması gerekmektedir (Çaha, 2000, s. 58).

Türk Medeni Kanunu'nun 101. Maddesine göre, vakıf kavramı “Gerçek veya tüzel kişilerin yeterli mal ve haklarını belirli ve sürekli bir amaca özgülemeleriyle oluşan tüzel kişiliğe sahip mal toplulukları" olarak tanımlanmaktadır (TBMM, 2017).

Devletin, sosyal yardımlar ve sosyal yardım kurumları aracılı̆̆ı ile yürüttüğü görevlerin yanı sıra, ekonomik güce sahip vatandaşların vakıflar kurarak, sosyal sorunların çözümünde devlete yardımcı olmaları, hem insani ve ahlaki görevleri, hem de yaşadıkları topluma karşı sosyal sorumluluk ödevleridir. Bu anlamda, vakıflar, belirtilen gereklilikler sonucu var olan/kurulan hukuki kurumlardır. Topluma yardım edebilme açısından, ahlaki ve insani ödevlerin yerine getirilmesinde en elverişli kurum vakıflardır denilebilir (akt. Doğanlı, 2015, ss. 50-51).

Vakıflar, karşılıklı dayanışma ve ihtiyacı olanlara iyilik yapma duygusunu hukuki statüye kavuşturan ve ona süreklilik sağlayan, tüzel kişiliğe sahip hukuki ve sosyal kurumlardır (Özaydın, 2003, s. 4). Vakıflar uzun vadeli olarak kurulur, bireyin ve toplumun refahını esas alarak, sosyal sorumluluk temeline dayanır. Sosyal sorumluluk ise genel olarak, toplum yararı güderek, çevresel ve toplumsal sorunların çözülmesi, toplum yaşamında kültürel ve sosyal olarak olumlu değişimin sağlanabilmesi için farkındalık yaratmanın ve faaliyetlerin gerçekleştirilmesidir.

Araştırmanın konusu gereği vakıf imajının ölçülebilmesi için bilinirliğin yüksek olduğu varsayılan ve bir kurucu lidere sahip olan TEMA Vakfı seçilmiștir. TEMA Vakfı'nın resmi web sitesinde, vakfın kuruluşu şu şekilde anlatılmaktadır (Tema, 2017):

Hayrettin Karaca ve A. Nihat Gökyiğit, 1992 yılında TEMA Vakfı'nı birlikte kurdular. Amaçları Anadolu'da yaşanmakta olan erozyon ve çölleşme tehlikesine kamuoyunun dikkatini çekmekti. Hedefleri ise bu mücadelenin devlet politikası haline gelmesine katkı sağlamaktı. TEMA'nın "Türkiye Çöl Olmasın" sloganı toplumda büyük yankı uyandırdı. Illk kez önlem alınmazsa Türkiye’nin çöl olma tehlikesi ile karşı karşıya olduğu bu kadar yüksek sesle dile getirilmişti. TEMA Vakfi'nın kuruluş döneminde, doğa koruma konusu ülke gündeminde bugünkü kadar öne çıkmamıştı. Kamuoyu doğadaki bozulmaların farkına yeni yeni varmaya başlamıştı. Sosyal sorumluluk kavramı henüz gelişmemiști, iş adamları hayırseverlik adı altında çalışmalar yürütüyordu. 1992 Haziran'ında Brezilya'nın Rio de Janerio kentinde yapılan dünyanın ilk "Yeryüzü" Zirvesi, devletlerin insanın ekosistemler üzerinde yarattığı tahribatı kabul etmesi ve buna karşı verilen mücadeleleri küreselleștirerek ön plana çıkarması açısından önemli bir dönüm noktası oldu. Zirve, aynı zamanda sivil toplumun güçlü bir aktör olarak sahneye çıkmasında önemli rol oynadl. "Toprak Yaşamdır" sloganıyla bugün 25. yașını kutlayan TEMA Vakfi, Rio Zirvesi'nden sadece birkaç ay sonra, 11 Eylül 1992 tarihinde kuruldu (Tema, 2017). TEMA Vakfi kurucu lideri olarak Hayrettin Karaca, doğa ve erozyon için verdiği mücadelenin sonucu olarak ulusal ve uluslararası 51 tane ödül aldığını belirtmektedir. Bunlardan biri Birleșmiş Milletler ödülü (DHA, 2017), bir diğeri de Alternatif Nobel olarak kabul edilen Doğru Yaşam (youtube.com, 2017) ödülüdür.

Bilinirliği yüksek olan bir vakıf varsayılmasının yanı sıra, TEMA'nın 1992 yılından bu yana 25 yıldır faaliyet gösteriyor olması, Türkiye'nin çevre ve çölleşme sorunlarını ilk defa gündeme getirmesi, gerçekleştirmiş olduğu çok sayıda önemli ve başarılı proje, ülkedeki çok sayıdaki yerli ve yabancı kurumun desteğini almış olması, tüm ülkede çok sayıda temsilciliğinin olması, aldıkları çok sayıda ulusal/uluslararası ödül ve en önemlisi Hayrettin Karaca gibi ömrünü TEMA Vakfi'na ve vakfın faaliyetlerine adamış (Tema, 2017) ‘dünyayı kurtarmaya karar verdim’ iddiasına sahip (youtube.com, 2017), doğa aşkı ve doğayı koruma heyecanıyla yaşayan, çalışan (youtube.com, 2017) bir lidere sahip olması, araştırma için seçilmesinin diğer nedenlerini oluşturmaktadır. 


\section{Lider Kavramı ve Bir Vakıf Lideri Olarak Hayrettin Karaca}

İnsanlık tarihi kadar uzun bir geçmişi olan liderlik, alan yazında değişik açılardan ele alınarak incelenmiştir. Küreselleşmenin etkisiyle dünyadaki dengeler değişmiştir. Günümüzde bu değişimi etkin ve etkili yönetebilecek, ufuk açabilecek liderlere çok daha fazla ihtiyaç vardır. Lider kavramı 1300'lü yıllarda ilk defa kullanılmıștır. Liderlik kavramı ise, 19. yüzyılın ilk yarısında İngiliz Parlamentosu'nun politik etkisi ve kontrolü konusundaki yazımlarda kullanılmaya başlanmıștır (Bass, 1981, s. 7). Pek çok insan liderlik ile ilgili olarak "Lider olunmaz, lider doğulur" ilkesini savunmakta ve dolayısıyla da liderliğin öğretilemez bir yetenek olduğunu kabullenmektedir. Ancak bazı araștırmacılar, liderlerin yerine getirmesi gereken görevleri, aslında tanımlanması mümkün olan görevler olarak ifade ederek bu savı çürütmekte ve liderliğin insanlara öğretilebilecek bir olgu olduğunu belirtmektedir. Lider, bireyin tek başına ulaşamayacağı bir takım ihtiyaçları ve amaçları belirleyebilen, bunları yerine getirebilmek için kendisiyle birlikte hareket etmekten yorulmayacak bireylerle bir araya gelerek bir grup oluşturabilen, bu gruba yön veren, örgütleyen ve bu grubu belirlenmiş olan strateji çerçevesinde harekete geçirebilme becerilerine sahip olan kişiye denir (Begeç, 1999, s. 12). Bu açıdan bakıldığında liderin iyi ve etkili bir iletişim yeteneğinin olması, kendisini takip edenlerle aynı duyguları ve tavrı paylaşabilmesi, grubun amacına ulaşabilmesi için gerekli tüm iş ve eylemleri yapabilmek için gerekli yetkinliklere sahip olması gerekmektedir. Türkiye'de faaliyet gösteren STK liderlerinin taşıması gereken özellikleri Sezik (2019, s. 123) aşağıdaki gibi belirtmektedir:

Türkiye'de özellikle 1990'l yıllardan itibaren sivil topluma olduğundan fazla önem verilmesi, STK yönetici kadrolarının bu kurumları siyasete atlama tahtası olarak görmeleri ve güç devşirme alanı olarak değerlendirmelerine yol açmıştır. Oysa gönüllü kuruluşlarda liderlik yapan kişi ve yönetim kadroları kuruluşun misyonu konusunda tutkulu olmalı, güçlü insan ilişsilerine sahip örgütün vizyonunu en iyi aktaracak şekilde iletişim yeteneğine sahip olmalı, bağış toplama konusunda kendine güvenmeli ve STK'nın hedefleri ile yönetim kadrosunun hedeflerini birleştirmelidir.

Çalışmada TEMA Vakfının kurucu lideri olarak ele alınan Hayrettin Karaca'nın da bir liderde aranan vasıfların pek çoğuna sahip olduğu görülmektedir. Hayrettin Karaca'nın yaşam öyküsü de bunu desteklemektedir.

Hayrettin Karaca 1922 tarihinde Balıkesir'e bağlı Bandırma ilçesinde trikotaj atölyesine sahip bir ailenin çocuğu olarak dünyaya gelmiştir. Lise eğitiminden sonra trikotaj atölyesinin başına geçen Hayrettin Karaca, Karaca trikolarını tanınmış bir marka hale getirmiş ve ilk triko ihracatını gerçekleştirmiştir. Edebiyata ve doğaya karşı ilgisi olan Hayrettin Karaca 50'li yaşlarda işlerini oğluna devrederek Anadolu'yu karış karış gezmeye ve ağaç ve bitki örnekleri toplamaya başlamıștır. Bu geziler sırasında Türkiye'nin hızla çölleştiğinin farkına varan Hayrettin Karaca bu konuda toplumu bilinçlendirmek amacıyla, 1992 yılında sanayici arkadaşı Nihat Gökyiğit'le birlikte TEMA Vakfı'nın kurulmasına öncülük etmiştir. Hayrettin Karaca, doğayı korumak adına başlattığı bu hareketten dolayı, gerek yurt içi gerekse yurt dışında pek çok ödüle layık görülmüştür. En son 2013 yılında Birleșmiş Milletler tarafından "Orman Kahramanı Ödülü" alan ve genellikle giydiği kırmızı kazakla hatırlanan Karaca bugün 95 yașindadır (biyografi.info, 2017).

Hayrettin Karaca, TEMA Vakfi'nın kurucu lideri olarak hayatını vakfın faaliyetlerine adamıștır. Lideri takip eden insanlar genellikle lideri kendilerine örnek alırlar ve liderin gücüne ve bilgisine inandıkları zaman başarıya ulaşabilirler (Ekici, 2006, s. 17). Hayrettin Karaca da bir lider olarak pek çok takipçisi tarafından örnek alınan bir kişiliktir. Bunun yanında iyi bir liderin sergilemesi beklenen bazı görev ve davranışlar bulunmakla birlikte, bunların büyük bir kısmına Hayrettin Karaca sahiptir. Bu görev ve davranışlar şu şekilde sıralanabilir (Çetin, 2008, s. 46); 
Başarılı bir strateji belirleyebilmesi: Liderin belirleyeceği strateji değișikliği hissettirmeli, yaratıcı olmalı, takipçilerini yönlendirmeli ve insanların kendileri yapacakları görevlere adamalarını sağlamalıdır. Belirlenen strateji öyle inandırıcı, cesur ve ulaşlabilir olmalı ki insanlar tüm zorluklara rağmen izleyecekleri yolun gitmeye değer olduğunu algılayabilmelidir. Bir sivil toplum hareketi olan TEMA Vakfı da, Türkiye'nin en uzak noktasındaki köyünden, en merkezdeki șehrine kadar, bașta topraklar olmak üzere doğal varlıklara sahip çıkmak ve korumak için TEMA temsilciliği, genç TEMA, mezun TEMA gibi yaratıcı stratejiler belirlemektedir. TEMA Vakfi'nın bugün ülke genelinde 400.000'i aşan ve her geçen gün artmakta olan kendini doğaya adamış TEMA gönüllüsü bulunmaktadır. Bu gönüllüler TEMA Vakfı'nın kurucusu olan Hayrettin Karaca'nın liderliğinde doğal varlıkların korunması için çalışır, çevresel sorunların çözümü için yasal her yolu yılmadan dener, inisiyatif alır, yapıcıdır, doğruları söylemekten çekinmez. Hayrettin Karaca'nın geçmişte doğa adına yapmış oldukları sayesinde takipçileri de kendisine inanmış ve onun gibi doğa sorunlarına karşı yüksek duyarlılık göstermişler ve her daim çözüm odaklı olmuşlardır (Tema, 2017).

İşin özünü belirlemesi: İșin özünü belirlemek önceliklerin belirlenmesinde atılacak ilk adımdır ve bir liderin gerçekleștirmesi gereken en önemli sorumluluktur. Bu nedenle iyi bir lider, öncelikle vizyon ve misyon belirlemelidir. Belirlenen misyon tüm takipçiler tarafından benimsenmeli ve başarmak için çaba harcanmalıdır. Liderin takipçilerinin bir misyon etrafında toplanması, onları birbirine bağlayacaktır. Liderin bu noktada dikkat etmesi gereken nokta, misyonu belirlerken hedeflerin günlük rutin işlerden oluşmasını önlemek, hatta cesaret ve fedakârlık gerektiren hedefler haline dönüştürmektir. Nitekim Hayrettin Karaca'nın liderliğinde kurulan TEMA Vakfı'nın misyonu doğal varlıkları korumaktır. Bu misyon ıșığında hedeflenen bilim temelli çalışan, toplumsal barıșa inanan, halkla bütünleșen, gönüllü, bilinçli ve öncü bir STK haline dönüşmektir. Bu hedeflere ulaşabilmek için Hayrettin Karaca da konforlu evinden ayrılıp çevre köylere gitmiş ve hasat zamanı köylülere yardım ederek fedakârlıklar yapmıștır. Kendisi, anılarını dile getirirken gittiği köylerde "Mısır soyar, harmanda döven kullanır, tarla bekçiliği yapardım" demektedir (biyografi.net, 2017). Doğa ile iç içe yaşayan birisi olarak Hayrettin Karaca, Türkiye'deki insanın olumsuz etkisinden kaynaklanan hızlı çölleşmenin farkına vararak 1992 yılında TEMA'yı kurmuş ve bu vakfın özünde neler yapması gerektiğini belirlemiştir.

Insanları ikna edebilmesi: Liderin ikna edici olabilmesi için öncelikle güvenilir olması, söyledikleri ile yaptıklarının birbiriyle uyumlu olması gerekmektedir. Özellikle değişim dönemlerinde liderin insanları ikna edebilmesi için onlarla gereğinden daha fazla iletişim kurması gerekmektedir. Bu sayede insanların hangi konularda bilgi sahibi olduklarını ve hangi konularda da yeterince bilgiye sahip olmadıklarını anlayabilirler. Hayrettin Karaca'nın doğayı koruma hakkında daha bilinçli olmak için oluşturduğu STK'nın hiçbir kar amacı gütmüyor olması ve kendisinin yaşına rağmen özverili bir şekilde bu kuruluş için çalışmış olması, insanların ona karşı güven duymasına neden olmuştur. Hayrettin Karaca'nın 90'lı yıllarda doğa konusunda bir bilinç oluşturmak istemesi, Türkiye'de doğaya bakıșı değiștirmek için ilk defa yapılan bir hareketti ve Hayrettin Karaca insanları bu konuda ikna edebilmek için köy köy ülkenin dört bir yanını gezmiştir. Bu amaçla bazen bir köy kahvesinde 5-6 kişiye, bazen ise akademisyenler ve hükümet görevlilerinden oluşan bilimsel bir topluluğa çevre bilincinin oluşabilmesi için toplantılar düzenlemiștir.

Harekete geçebilmek: Bir liderin zamanında hareket geçebilmesi önemlidir. Özellikle de belirsiz ortamlarda zor kararların verilmesi gerektiği zamanlarda lider karar verebilmeli ve harekete geçmelidir. Liderin zamanında karar veremeyip harekete geçememesi durumunda, takipçilerinde kaygı, çaresizlik ve güvensizlik oluşur ve lider zayıf bir kişi olarak algılanmaya başlar. Liderin yeteneklerine, özgüvenine ve etkinliğine 
inanmayan takipçiler, liderin belirlediği misyonu yerine getirmek istemeyebilir. Liderin takipçilerinde güven, kesinlik, güç, cesaret ve inanç yaratması gerekmektedir. Zamanında doğru kararlar vererek harekete geçen liderler bunları başarabilmektedir. Hayrettin Karaca da 50’li yaşlarında her şeyi göze alarak kendisini adadığı doğal hayatı koruma adına harekete geçmiş ve 1980 yılında Yalova yakınlarında kendisine ait 13,5 hektarlık araziyi Türkiye'nin ilk özel Arboretum'una dönüştürmüştür. Hayrettin Karaca, bununla da kalmayıp yurt içinde ve yurt dışında gezdiği her yerden tohumlar toplamış, botanik bahçelerini gezmiş ve bağlantılar kurmuştur. Bugün Yalova'daki Karaca Arboretum'u dünyadaki pek çok botanikçi tarafından bilinmektedir. Yine kurucusu ve onursal başkanı olduğu TEMA Vakfını da 1992 yılında hayata geçirerek belirlemiş olduğu misyon için harekete geçmiştir.

İyi bir liderin gerçekleștirmesi gereken bu görevlerin yanında takipçilerini etkileyebilmesi belli bir süreci gerektirmektedir. Liderlik etkileme süreci olarak adlandırılan bu süreç 5 aşamadan oluşmaktadır. Bunlar (Çetin, 2008, s. 56);

Pozisyon: Liderler sahip oldukları pozisyondan kaynaklanan haklar ve yetki nedeniyle güçlü hale gelirler. Bu güç onların liderlik becerilerinin daha da güçlü hale gelmesini sağlar. Ancak liderlik sadece o pozisyonun vermiş olduğu güç ile başkalarını etkilemek değildir, gerçek liderler başkaları tarafından istekle ve inançla izlenmektedir. Özellikle STK liderlerinin takipçileri o lidere inandıkları ve STK'ya katkı sağlamak istedikleri için lideri takip etmektedirler. Hayrettin Karaca da TEMA Vakfının fikir babası ve kurucusu pozisyonunda bir lider olarak yaptığı konuşmalarda, özellikle çocuklarla asla emir kipi ile konuşmadığını, onların kendi kendilerine ne yapacaklarını bulmalarını istediğini belirtmektedir (biyolojigunlugu.com, 2017).

İzin: İkinci aşamada lider, zorunlu olmadıkları halde takipçilerini kendisi için çalışmasını sağlayabilmelidir. Bu aşamada liderin ne kadar bilgiye ve uzmanlık gücüne sahip olduğu değil, liderin takipçileri tarafından ne kadar anlaşıldığı ve de önemsendiği önemli olmaktadır. Liderin etki derecesi de bununla sınırlıdır. Lider, bu aşamada takipçileri ile ilişkisinin sağlam ve uzun süreli olması için enerjisini ve dikkatini takipçilerinin istek ve ihtiyaçları üzerinde yoğunlaştırır. Hayrettin Karaca, TEMA ile doğayı korumak ve kurtarmak adına başlattığı hareket, bugün pek çok gönüllü tarafından devam ettirilmektedir.

Ürün: Ürün aşamasında takipçiler lideri ortaya koydukları ürün ile izlerler. Bu aşamada artık kazanılmış bir ivme söz konusudur ve sorunlar en az çabayla çözülebilir hale gelmiştir. Takipçiler sonuca yönelmiştir ve herkes bir amacı gerçekleștirmek için birleşir. Hayrettin Karaca'nın bir lider olarak ürünü 13,5 hektar arazi üzerine kurduğu Türkiye'nin ilk özel Arboretum'u ve TEMA Vakfıdır. Takipçilerin hepsinin amacı TEMA Vakfı aracılığıyla ülkedeki orman, çayır, mera ve tarım alanlarının, su ve bitki gen kaynaklarının, doğanın korunması ve erozyonun önlenmesi için çaba harcamaktır.

Insan Gelişimi: Bir lideri güçlü yapan şey başkalarını da güçlendirebilmesidir. Lider, bu aşamada takipçilerinin kişisel gelişimlerine katkıda bulunarak kalplerini kazanır. Başarılı liderler, öğretilebilir bakış açısını başkalarının geliştirilmesinde özellikle kullanırlar. Hayrettin Karaca, takipçilerinin TEMA Vakfı aracılığıyla en küçükten en büyüğe kadar doğa konusunda bilgilendirilmeleri için değişik programlar hazırlamıştır. Örneğin TEMA Vakfı'na gönüllü olabilmek 0-13 yaș, 14-24 yaş ve 25 yaş ve üstü olarak her yaş grubuna dağıtılmaya çalışmıştır. Küçük yaşlarda TEMA Vakfı için aktif çalışan bir takipçinin doğaya bakıș açısı olumlu yönde değişmektedir.

Kişilik: Liderin takipçileri lideri tutarlı kişiliği ve sahip olduğu kişilik özellikleri için izlemektedir. Liderin söylemleri ile yaptıkları arasında bir tutarlılık varsa takipçileri onu inandırıcı bulmaktadır. Doğayı korumak adına tüketimin olabildiğince az olmasını savunan, ihtiyaç kadar tüketilmesi gerektiğini söyleyen biri olarak Hayrettin Karaca, her ortama üzerinde aynı kırmızı kazakla katılarak bunu teyit etmektedir. 
Sonuç olarak günümüzde iyi bir lider, doğru amaçlar belirleyebilen, iyi iletişim kurabilen, güvenilir, saygılı olan, saygı duyulan, bireylerin yaratıcılıklarını destekleyen, yeni fikir ve projelere firsat tanıyan, geleceği ve başarıyı görebilen, kurumunun bütünsel başarısı için çabalayan, kurumunu temsil etmenin sorumluluğunu taşıyan kişidir. Kurum lideri kar amacı güden ticari kurumlar kadar, kar amacı gütmeyen STK'lar için de önemlidir. Ticari bir kurum için imaj oluşturma açısından bu kadar önemli olan lider kavramının, vakıflar için de önemli olduğu düşünülmektedir.

\section{Vakıfların Kurumsal İmajı ve İmaj Üzerinde Liderin Etkisi}

İmaj, herhangi bir olgu hakkında, bireyin çeșitli iletişim kanalları aracılı̆̆ıyla elde ettiği bilgileri değerlendirmesi, yorumudur. İmaj, sürekli aynı kalmamaktadır. Süreç içerisinde her bireyin zihninde yavaş yavaş ve birikimsel olarak biçimlenen imgeler bütününe dönüşmektedir (Tolungüç, 2000, s. 12).

Kurumların, sadece somut varlıkları ya da görünümleri itibariyle değil; toplum içinde oynadığı rol, faaliyetleri, olay ve durumlara yaklaşım biçimiyle kısacası kendi kişiliği ile onu diğerlerinden ayıran ve paydaşları tarafından diğerlerinden farklı algılanmasına yol açan bir imajı vardır. Bu imaj, kurumsal imaj olarak adlandırılır (Bakan, 2005, s. 14). Diğer bir ifadeyle, kurumsal imaj, bir kurumun paydaşları tarafından nasıl algılandığıdır. Burada kurumun tüm amaçlarının ve planlarının nasıl algılandığı önemlidir. Kurum imajı, kurumun ürünlerini, yönetim tarzını, iletişim faaliyetlerini ve dünya çapındaki diğer faaliyetlerini olumlu ya da olumsuz olarak etkiler (Okay, 1999, s. 259). Kurum imajı, kurumun hedef kitlesinin kurum hakkında sahip olduğu somut düşüncelerini, dışarıdaki grupların kurumu nasıl algıladığını ya da kurumun "olmasını istediği" durumu ifade etmektedir (Öztürk ve Şardağı, 2018, s. 120).

Bir kurumun varlığını devam ettirebilmesi, büyümesi, başarılı olabilmesi, paydaşlarından destek alabilmesi, nitelikli elemanları istihdam edebilmesi, herhangi bir krizden mümkün olan en az zararı alarak çıkabilmesi için güçlü bir kurum imajına ihtiyacı vardır. Kurumsal imaj, birçok kuruma rekabet üstünlüğü sağladığı gibi, iç ve dış çevresiyle uyum içinde bulunmasına da katkı sağlar. Diğer yandan kurumların imajı olumlu hale geldikçe, kuruma yönelik işbirliği ve destek de artmaktadır (Tașkın ve Dönmez, 2005, s. 7).

Kurumsal imaj, kurum için önemli bir varlıktır. Diğer varlıklar gibi imaja da, şayet doğru yönetilmezse değerini kaybedecek bir yatırım olarak bakılmalıdır (Schukies, 1998, s. 31). İmaj oluşumu için, bir kurum hakkında detaylı bilgi sahibi olmak da gerekmemektedir. Kurum hakkında yeterli bilgiye sahip olunmasa bile ağızdan ağıza iletişim, reklam ve sosyal medya aracılığıyla, hedef kitlenin zihninde kurum imajı oluşabilmektedir (akt. Marangoz ve Biber, 2007, s. 175). Bu durum, farkındalığın arttırılması için bir avantaj olabilirken, yanlış bilgilerin ağızdan ağıza aktarılması sonucu olumsuz imaj oluşturulmasına sebep olabilecektir. Bu durumda imaj oluşumunun tesadüflere bırakılmaması, imajı oluşturan tüm kriterlerin dikkatle yönetilmesi önem taşımaktadır.

Kurumsal imajı oluşturan en etkili değişken, yönetimdir ve buna bağlı olarak liderdir (Ballen; 1992, s. 31). Kurum imajını ölçmeye yönelik bir araştırmaya katılanların \% 80'inden fazlası, kaliteli bir yönetimin kurumun en önemli özelliği olduğunu vurgulamıştır (Bromley, 1993, s. 17). Toplum kadar liderler de güçlü ve olumlu bir imaj programına yatırım yapmanın önemini ve sağlayacağı katkıları; kısacası hem kendi önemlerinin hem de kurumsal imajın öneminin farkındadırlar (Gupta, 2002, s. 2). Kadıbeşegil de (1999, s. 36), benzer şekilde aynı zamanda bir yönetici olan liderin gücünü, kurumsal imaj oluşturmada etkili olabilecek stratejik araç olarak vurgulamaktadır. 
Kurumun görünen yüzü liderler, kurum imajı ve itibarı üzerinde en etkili unsurlardan biridir. Kurumu kamuoyu ile buluşturan, aracı rolünü üstlenen lider, kurum felsefesini, misyonunu ve vizyonunu yansıtan ayna görevi görmektedir. Bu nedenle kurumu temsil eden liderin, kuruma transfer edilmesini istemediği her türlü davranış ve açıklamadan kaçınması gerekir. Çünkü lider, kurumdan bağımsız olarak algılanamaz (Peltekoğlu, 2014, s. 581).

STK'ların kurumsal imajlarının oluşumunda, misyonları çerçevesinde sundukları çözüm önerileri ve bunun toplum içindeki yansıması önemlidir. STK'ların toplum içerisinde kabul edilmesi, gelir ve gönüllü desteği elde etmesinin kolaylaşması için olumlu bir imaja sahip olması gerekmektedir (Öztürk ve Şardağı, 2018, s. 120). Toplum yararı için faaliyet gösteren bir STK olan vakıflar da, bir kurum olarak belirli bir imaja sahiptirler. Vakıf imajı, bir vakfın hedef kitlelerince algılanış tarzı, kamuoyunda olușturduğu genel izlenim, vakfa duyulan saygınlık ve itibar, vakfın faaliyet alanlarında sağlanan destek ve oluşturduğu pozitif söylemlere dayalı görüntülerin tamamı olarak tanımlanabilir (Doğanl, 2015, s. 50).

Vakıfların, güçlü imaj yaratarak her ne kadar iş hacmini arttırmak gibi ticari bir amaçları söz konusu olmasa da, vakıflar da olumlu imaj yaratmak zorundadırlar. Bu sayede, devlet kurumları, yerel yönetimler, kamuoyu, ticari kurumlar, medya, halk hatta diğer vakıfların desteğini almaları kolaylaşacaktır. $\mathrm{Bu}$ durum vakıfların kuruluş amaçlarına ulaşmaları buna bağlı olarak varlıklarını devam ettirebilmeleri açısından hayati önem taşımaktadır. Çünkü vakıfların en önemli gelir kaynakları paydaşlarının bağışları ve desteğidir. Örneğin TEMA Vakfı'nın sayfası incelendiğinde bağıș ve destek bölümü görülecektir (tema.org.tr, 2017). TEMA da bir vakıf olarak bireysel ve kurumsal destekçilerin bağışlarıyla, gönüllülerin destekleriyle faaliyetlerini sürdürmektedir. Bu nokta çok kritiktir. Çünkü bireysel ya da kurumsal hiç bir bağışçı, hakkında olumlu imaja sahip olmadığı bir vakfa mecburi herhangi bir zorunluluk olmazsa, kendi iradesiyle bağıșta bulunmak istemez. İmajı sarsılan vakıfların, imaj tazelemeleri ve kamuoyunun desteğini tekrar kazanmaları pek kolay olamamaktadır. Bağıșta bulunmanın amacına uygun olarak her bağışçı, bağışlarının toplum yararına kullanılacağı beklentisi içindedir. Hatta bağışların toplumsal sorunların çözümüne katkıda bulunacağından emin olmak, bağışta bulunduğu vakfa güvenmek ister. Olumlu imaja sahip olan vakıflar, bu imaj sayesinde gelirlerini, gönüllü desteklerini, kamu ve özel kurumların desteğini alarak vakfın kuruluş amacına ulaşabilmek için faaliyetlerine devam edebileceklerdir. Bu durum vakfın sürdürülebilirliği açısından çok önemlidir.

Güçlü ve güvenilir bir vakıf imajına sahip bir vakıf konumuna ulaşmak, vakfı kamuoyunda söz sahibi olan bir konuma kavuşturacaktır. İlk olarak yapılması gereken, söz konusu vakfın sahip olduğu imajın tespit edilmesi; halkla ilişkiler yöntem ve teknikleri ile de bu imajın güçlendirilmesidir. Ancak cevabı aranan soru, oluşturulması arzu edilen imajın hangi şartlarda gerçekleştirilecek olduğudur (Doğanlı, 2015, s. 50).

Vakıflar, toplumun ihtiyaçları doğrultusunda toplumun içerisinden ortaya çıkmakta, yarattıkları değerler topluma kazanım olarak geri dönmektedir. Bu kurumlar, kuruluş amaçlarını seçerken, faaliyetlerini devam ettirirken toplumsal öncelikleri tahmin etmek ve buna göre faaliyetlerini planlamak zorundadırlar. Yapılan tüm faaliyetler vakfın imajını da etkileyecektir. Bu faaliyetlerin her aşamasında, en önemli görev vakfın liderine düşmektedir.

Liderin, kurumsal imaj üzerine etkilerinin olması kaçınılmaz görünmektedir. Vakıf liderleri, vakfın imajından doğrudan sorumludur ve vakıfların imajını yönetmek zorundadır. İmajın yönetilmemesi halinde, vakıf imajı kurum dışı faktörlerle şekillenir. Bu durumda vakfın kendi iradesi dışında oluşan kurumsal imajını etkilemesi söz konusu olamaz. Vakıflar, ne kadar önemli faaliyetler yürütürlerse yürütsünler, kendilerini kamuoyuna tutarlı, dengeli ve sürekli iletişimle anlatamadıklarında kamuoyunun 
desteğini almaları zor olabilmektedir. Her geçen gün artan toplumsal sorunlar, başarısız STK'ların güven sarsıcı etkileriyle mücadele edebilmek açısından önem taşımaktadır.

Vakıf imajının, oluşturulabilmesi için samimiyet, halkla özellikle hedef kitleyle iç içe olma, bilgilendirme, huzur verme, gerçekçi olma, mutluluk verme, kurumsal olma, sorumluluklarının bilincinde olma, başarılı, çalışkan, saygın olma, kendine özgü olma, ilham verici, güçlü, bağımsız, cesur, alanında lider, gönüllüleri motive eden ve benzersiz olma gibi özelliklerinin yanı sıra, vakfın sağlayacağı güven, alanında lider olma gibi temel özelliklerde gereklidir (Okay, 2003, Bakan, 2005, Tuna ve Tuna, 2007, Doğanll, 2015).

Bakan'ın (2005, s. 39) ifade ettiği gibi kurumsal imajın yerine getirdiği önemli bir işlev, iç ve dış hedef kitle üzerinde inandırıcılık, güven yaratmak ve bunu sürdürmektir. $\mathrm{Bu}$ durum kuşkusuz vakıflar için de geçerlidir hem kurum içinde, hem de dışında oluşturulacak imajın ise, tek ve inandırıcı olabilmesi için kurum gerçeğiyle uyum içinde olması gerekmektedir. TEMA temel değerleri arasında, güvenilirlik, saygınlık, bilimsellik olduğunu vurgulamaktadır (tema.org.tr, 2017). TEMA'nın güvenilir bir tablo çizmesinde bir diğer etken de kurumsal ve bireysel destekçilerdir ve TEMA'nın başta Koç Holding ve Koç Holding'e bağlı kurumlar olmak üzere çok sayıda destekçisi bulunmaktadır (tema.org.tr, 2017). Vakfın gerçekleştirmiş olduğu projeler ve faaliyetler incelendiğinde, çok sayıda başarılı ve çalışkan bir profil sergilediği gözlenmektedir (tema.org.tr, 2017).

TEMA misyonunu dürüstlükle ilişkilendirmektedir. TEMA'nın misyon, politika ve etkinlikleri dürüstlük, şeffaflı $k$ ve açıklık ilkelerine dayanır. Vakfın internet sitesi, en fazla bilgiyi kamuya ve tüm paydaşlarına vermek amacı ile ayrıntılı olarak oluşturulmuştur ve sürekli olarak güncellenmektedir. $\mathrm{Bu}$ güncellemeler kamuoyunun bilgilendirilmesi açısından önemlidir (tema.org.tr, 2017).

Vakfın güçlü bir imaja sahip olabilmesi için, emsallerinden farklı algılanması ve tanınma oranının yüksek olması gerekmektedir. Farkındalık yaratmak ve bilinirliğinin arttırılması da bir gerekliliktir (Doğanlı, 2015, s. 50). Kurum imajını ölçmek için değiş̧ik yöntemlerin kullanıldığı görülmektedir. Ancak, bütün yöntemlerin ortak sorunu geliştirilen ölçüm araçlarının standartlaştırılması olmuştur. Alanyazında bu konuda sağlanan bir düşünce birliği olmadığını görmekteyiz (Schwaiger, 2004, s. 51).

Anlaşıldığı üzere kurumların güçlü bir imaja sahip olması kadar vakıfların da güçlü bir imaja ihtiyaçları bulunmaktadır. Vakıfların, olumlu imaja sahip olması kadar bu imajı koruması ve devam ettirmesi de önem taşımaktadır. Ülkede vakıflar ve birlikleri de kapsayan on binlerce sivil toplum kuruluşu bulunmaktadır. Bunların hepsini tanımak mümkün olamasa da, tanınan, hatırlanan STK'ların çok çok azının lideri bilinmekte, hatırlanmaktadır ya da aktif olarak ön plandadır diyebiliriz.

\section{Amaç ve Yöntem}

Kurumsal imaj, bir kurumun kamuoyu tarafından algılanmasında güçlü bir etkendir. Kamuoyu genellikle kurum imajından etkilenir ve kurum hakkında bir yargıya sahip olur. Aynı şekilde vakıflar da, kar amacı gütmeyen kurumlar olarak kamuoyu desteğini alabilmek için olumlu imaj yaratmaya çalışırlar. Tüm kurumlarda olduğu gibi vakıfların da olumlu imaj yaratmasına yardımcı olan etmenler bulunmaktadır. Bu etmenlerden biri de liderdir. Nitekim Ballen'in de (1992, s. 31) belirttiği gibi kurumsal imajın oluşturulmasında en etkili değişken yönetim ve liderdir.

TEMA, lideri ile beraber anılan, adeta liderle bütünleşen, lideri bilinen ve ülkemizde sayısı çok az olan vakıflardan biridir. Bu nedenle de araştırma için TEMA ve Hayrettin Karaca seçilmiştir. Bu araştırmanın amacı, TEMA Vakfı kurucusu Hayrettin Karaca'nın bir lider olarak TEMA Vakfı'nın imajı üzerindeki etkisinin kamuoyu tarafından nasıl algılandığını belirlemeye çalışmaktır. Bu bağlamda geliştirilen araştırma soruları şöyledir: 
-Bir lider olarak Hayrettin Karaca'nın liderlik davranışları ile TEMA Vakfı'nın imajı arasında bir ilişki var mıdır?

-Hayrettin Karaca'nın liderlik özelliklerinin TEMA Vakfı'nın imajı üzerinde etkisi var midır?

Bu çalışmada, genel tarama modeli yaklaşımı kullanılmış ve betimsel araştırma yöntemiyle, anket tekniği aracılığıyla veri toplanmıştır. Bu yöntemde "Değişkenlerin tek tek, tür ya da miktar olarak oluşumlarının belirlenmesi amacıyla yapılan tekil tarama modellerinde ilgilenilen olay, madde, birey, grup, kurum, konu vb. birim ve duruma ait değişkenler, ayrı ayrı betimlenmeye çalıșılır" (Karasar, 2009, s. 79).

Çalıșmada, kolayda örnekleme yöntemi kullanılmıștır. Araștırmacıların Facebook hesaplarından, anket linki verilerek TEMA Vakfı hakkında bilgisi olan Facebook kullanıcılarının ankete ulaşımı sağlanmıştır. Kolayda örnekleme yöntemine göre, araştırmacı kendi kolayına nasıl geliyorsa örnekleri o șekilde seçer (İslamoğlu ve Alnıaçık, 2014, s. 14). Anket formu, kwiksurveys.com'da 1 Ekim 2018-01 Kasım 2018 tarihleri süresince aktif kalmıștır. Facebook kullanıcısı, 354 kiși tarafından anket cevaplanmıștır. $\mathrm{Bu}$ araștırma bulguları, tüm Facebook kullanıcılarına ve tüm kamuoyuna genellenemez, sadece benzer hedef kitleler açısından yön gösterici olabilir.

Alanyazında kurum imajının ölçülmesi ile ilgili çalışmalar genellikle ticari kurumların kamuoyu üzerindeki imajının ölçülmesi (Gültekin ve Küçük, 2004; Tutar, 2007; Saraçoğlu, 2013) șeklindedir. STK'lar üzerinde bu bağlamda yapılan kurum imajı ve liderlik etkileşimi (Kilik, 2011), STK ve marka imajı ölçümü (Doğanlı, 2015), sivil toplum kuruluşlarında gelecek yönelimli lider performans profili (Özmutaf ve Kayalar, 2008), STK'larda liderlik ve iş tatmini ilişkisi ölçümü (Mufti vd., 2019), STK'ların örgüt hedeflerine ulaşabilmeleri için liderin önemi (Mwai vd., 2018), liderin STK'nın ünü üzerindeki etkisinin ölçümü (Mitchell, 2015), STK'ların başarısında liderin öneminin ölçülmesi (Çetin, 2013) şeklindedir. Yukarıda belirtilen bu çalışmalarda ağırlıklı olarak STK çalışanlarının, liderlerin, yöneticilerin görüşleri değerlendirilmiștir. Alan yazında, vakfın dışındaki hedef kitle üzerinde, liderin vakıf imajı üzerindeki etkisini ölçen bir çalışmaya rastlanılmamıştır. Dış müşteri de diyebileceğimiz vakfın hizmetlerinden etkilenen kişiler üzerinde liderin ve vakfın imajının ölçülmesi onların desteğinin de sağlanabilmesi için önem taşımaktadır. Çalışma, bu açıdan özgündür ve alanyazına katkı sağlayabileceği düşünülmektedir.

Kurum imajının ölçülmesinde, vakıflar ve ticari kurumlar farklılık göstermektedir. Ticari kurumların imaj ölçümünde ürün, hizmet, kalite, satış sonrası hizmetler, çalışanlar gibi pek çok değişken etkili olmaktadır. Bu nedenle alanyazındaki imaj ölçeklerinin dışında, vakıf imajı ölçümü için farklı bir soru formunun oluşturulmasına ihtiyaç duyulmuştur. Bu amaçla araştırmacılar tarafindan soru formunun oluşturulabilmesi için alanyazındaki imaj ve liderlikle ilgili çalışmalar taranmış ve soru formu yapılandırılmaya çalışılmıştır. Çalışmanın imaj soruları oluşturulurken Doğanlı'nın (2015) "STK (Vakıflar) ve Marka İmajı” başlıklı çalışmasından faydalanılmıştır. Liderlik soruları oluşturulurken ise Çetin'in $(2008$, s. 46) İstanbul Ticaret Odası için hazırlamış olduğu "Yöneticilerin Liderlik Stilleri, Değişim Yönetimi ve Ekip Çalışması Arasındaki İlişkilerin Çok Yönlü Olarak Değerlendirilmesi" başlıklı kitap temel alınmıştır. Ölçekte, TEMA'nın imajını ölçmeye yönelik 23 soru, Hayrettin Karaca'nın liderlik özelliklerini belirlemeye yönelik de 20 soru yer almaktadır. Sorular 5'li likert tipinde "1=Kesinlikle Katılıyorum" ve "5=Kesinlikle Katılmıyorum" olarak derecelendirilmiștir. Ölçekteki soruların güvenilirlik analizi yapılmıștır. Güvenilirlik analizi özellikle soru formunun ikinci bölümünde yer alan Hayrettin Karaca'nın liderlik özelliklerini belirlemek üzere sorulan 20 soru ile üçüncü bölümde yer alan ve TEMA Vakfı'nın imajını ölçmeye çalışan 23 sorunun tamamına uygulanmıştır. Güvenilirlik analizi sonuçları Tablo 1'de verilmektedir; 
Güvenilirlik analizi sonuçlarına göre Cronbach’s Alpha değeri liderlik ölçeği için $\alpha$ : 0,912 TEMA Vakfı İmajı ölçeği için ise $\alpha$ : 0,924 olarak bulunmuştur. İslamoğlu'na (2011, 139) göre alfa değeri eğer $0.80 \leq \alpha<1.00$ ise ölçek yüksek güvenilirliktedir.

\section{Bulgular}

Araștırmada öncelikle katılımcıların cinsiyet, yaş, medeni durum ve eğitim gibi demografik bilgilerinin yanı sıra herhangi bir STK'ya üye olup olmadıkları, TEMA'nın faaliyetleri ile ilgili herhangi bir bilgiye sahip olup olmadıkları gibi bilgiler de elde edilmeye çalışılmıștır. Araștırmaya katılanların demografik özellikleri, STK'lara olan duyarlılıkları ve TEMA konusundaki bilgileri ile ilgili veriler Tablo 2'de verilmektedir.

\begin{tabular}{|l|l|l|l|l|l|}
\hline Cinsiyet & $\mathbf{N}$ & $\mathbf{\%}$ & Yaş & $\mathbf{N}$ & $\mathbf{\%}$ \\
\hline Kadın & 193 & $\% 54,5$ & 17 ve altı & 5 & $\% 1,4$ \\
\hline Erkek & 161 & $\% 44,5$ & $18-24$ & 159 & $\% 44,9$ \\
\hline Medeni Durum & $\mathbf{N}$ & $\mathbf{\%}$ & $25-29$ & 50 & $\% 14,1$ \\
\hline Evli & 105 & $\% 29,7$ & $30-34$ & 44 & $\% 12,4$ \\
\hline Bekâr & 249 & $\% 70,3$ & $35-39$ & 33 & $\% 9,3$ \\
\hline Meslek & $\mathbf{N}$ & $\mathbf{\%}$ & $40-44$ & 22 & $\% 6,2$ \\
\hline Öğrenci & 180 & $\% 50,8$ & $45-49$ & 20 & $\% 5,6$ \\
\hline Öğretmen & 9 & $\% 2,5$ & 50 ve üstü & 21 & $\% 5,9$ \\
\hline Akademisyen & 69 & $\% 19,5$ & Ĕgitim & $\mathbf{N}$ & $\%$ \\
\hline Mühendis & 34 & $\% 9,6$ & İlköğretim & 4 & $\% 1,1$ \\
\hline Doktor & 7 & $\% 2$ & Lise & 164 & $\% 46,3$ \\
\hline Mimar & 0 & $\% 0$ & Ön lisans & 11 & $\% 3,1$ \\
\hline Sağlık Personeli & 1 & $\% 0,3$ & Lisans & 75 & $\% 21,2$ \\
\hline Teknik Personel & 7 & $\% 2$ & Yüksek Lisans & 63 & $\% 17,8$ \\
\hline Büro Personeli & 5 & $\% 1,4$ & Doktora & 37 & $\% 10,5$ \\
\hline İşçi & 3 & $\% 8$ & Bir STK'ya Üye & $\mathbf{N}$ & $\mathbf{\%}$ \\
\hline Memur & 9 & $\% 2,5$ & Evet & 51 & $\% 14,4$ \\
\hline Diğer & 30 & $\% 8,5$ & Hayır & 303 & $\% 85,6$ \\
\hline $\begin{array}{l}\text { Bir STK Faaliyetine } \\
\text { Katılındı mı? }\end{array}$ & $\mathbf{N}$ & $\mathbf{9}$ & TEMA'yı Duydunuz mu? & $\mathbf{N}$ & $\%$ \\
\hline Evet & 93 & $\% 26,3$ & Evet & 345 & $\% 97,5$ \\
\hline Hayır & 61 & $\% 73,7$ & Hayır & 9 & $\% 2,5$ \\
\hline & & & & & \\
TEMA Faaliyetleri & $\mathbf{N}$ & $\%$ & TEMA'nın Web Sayfasını & $\mathbf{N}$ & $\%$ \\
Biliniyor mu? & & & & & \\
\hline Evet & 295 & $\% 83,3$ & Hiç & 139 & $\% 39,3$ \\
\hline Hayırr & 59 & $\% 16,7$ & En az bir & 139 & $\% 39,3$ \\
\hline & & & İki ve daha fazla & 76 & $\% 21,5$ \\
\hline
\end{tabular}

Tablo 2. Katılımcıların Demografik Özellikleri ve STK ve TEMA Konusundaki Bilgileri ile İlgili Bulgular

Araştırmaya katılanların cinsiyet oranlarına bakıldığında eşit dağılıma çok yakın olduğu (\%54,5 kadın, \%44,5 Erkek) belirlenmiştir. Araştırmada soruların birbirine yakın oranlarda kadın ve erkek tarafından cevaplanmış olması, yapılan araştırmayı her iki cinsiyet için de genellemek açısından önemlidir. Katılımcıların büyük bir kısmı bekârdır $(\% 70,3)$ ve çoğunluğu 17-24 yaş $(\% 44,9)$ arasındadır. Örnekleme dâhil edilen katılımcıların büyük bir kısmı $(\% 46,3)$ lise mezunudur. Yarıya yakını ise lisans ve 
lisansüstü $(\% 49,5)$ eğitime sahiptir. Herhangi bir STK'ya üyelik konusunda, olumlu yanıt verenlerin toplam katılımcı sayısına oranla oldukça az olduğu $(\% 14,4)$ gözlenmiştir. Katılımcıların büyük bir çoğunluğu $(\% 73,7)$ herhangi bir STK faaliyetine de katılmamıştır. Buna rağmen ankete katılanların büyük çoğunluğu $(\% 97,5)$ TEMA Vakfı'nın varlığından ve faaliyetlerinden $(\% 83,3)$ haberdardır. Katılımcların \%60,8'i TEMA'nın web sayfasını ziyaret etmiștir.

Çalışmanın ikinci bölümünde lider ve imaj arasındaki ilişkiyi belirleyebilmek amacıyla değișkenler arasındaki doğrusal ilișkiyi gösteren (Pearson testi kullanılarak) korelasyon analizi yapılmıştır. Korelasyon katsayısı 0.629 ve anlamlılık düzeyi (Sig.) ise 0.000 olarak hesaplanmıștır. TEMA'nın imajı ile TEMA Vakfı lideri olarak Hayrettin Karaca'nın liderlik özellikleri arasında pozitif yönlü bir ilişki bulunmaktadır. Korelasyon analizi ile ilgili bulgular Tablo 3'te verilmiștir.

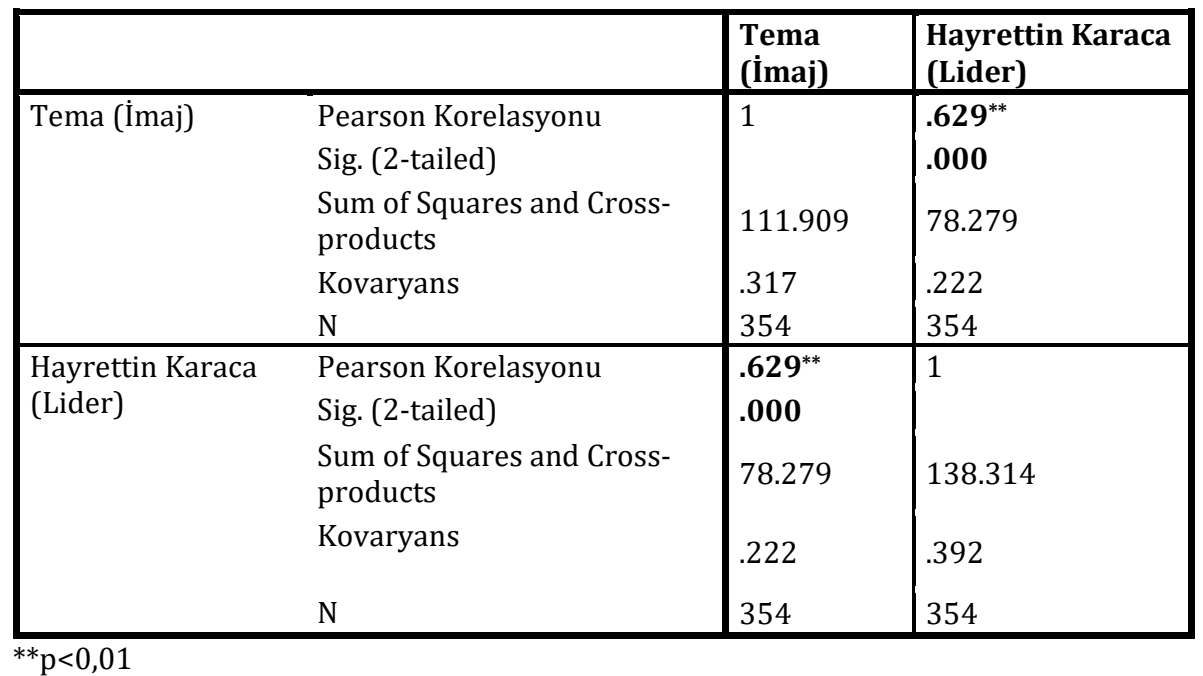

Tablo 3. Lider ile İmaj Arasındaki İlişkiyi Gösteren Korelasyon

Çalışmada TEMA Vakfı lideri olarak, Hayrettin Karaca'nın liderliğinin, TEMA Vakfı imajı üzerindeki etkisini ölçmek amacıyla Regresyon Analizi yapılmıştır. Regresyon analizinin yapılabilmesi için Hayrettin Karaca'nın liderlik özelliklerini belirlemek üzere sorulmuş 20 soru ile TEMA Vakfının imajı ile ilgili olarak sorulmuş 23 sorunun ortalaması alınmıș ve liderlik soruları bağımsız, imaj soruları ise bağımlı değișken olarak regresyon analizi gerçekleştirilmiştir. Regresyon modelinin analizi sonucunda, model istatistiksel olarak anlamlı bulunmuștur ( $\mathrm{F}=230.663, \mathrm{p}=0,00)$. Ayrıca modelin açıklama gücü olarak da değerlendirilen determinasyon katsayısı $R^{2}(0,396)$ olarak belirlenmiştir. Bu değer imaj ölçeği değişkeninin, bağımsız değişken tarafından yaklaşık \% 39,6'sının açıklandığı yani vakıfların toplam imajının \%39,6'sının lider etkisiyle şekillendiğini ifade etmektedir. Geriye kalan \%60,4'lük kısmını liderin dışında kalan ve imajı etkileyen diğer unsurlar oluşturmaktadır. Nitekim kurum imajını liderin yanında etkileyen ve modele dâhil edilmeyen çalışanlar, satış sonrası hizmet, reklamlar, ambalaj, fiziksel görünüm, endüstriyel ilişkiler gibi pek çok etmen bulunmaktadır (Güleç, 2014, s. 4). Regresyon analizi ile ilgili bulgular Tablo 4'te verilmiștir. 


\begin{tabular}{|l|l|l|l|l|}
\hline Model & R & R Kare & Düzeltilmiș R Kare & $\begin{array}{l}\text { Tahmini Standart } \\
\text { Hata }\end{array}$ \\
\hline 1 & 0,629 a & $\mathbf{0 , 3 9 6}$ & 0,394 & 0,43825 \\
\hline
\end{tabular}

Bağımlı Değişken TEMA'nın İmajı $R^{2}=0,396^{* *} \mathrm{p}<0,01$

Coefficients ${ }^{\mathrm{a}}$

\begin{tabular}{|c|c|c|c|c|c|}
\hline \multirow[b]{2}{*}{ Model } & \multicolumn{2}{|c|}{$\begin{array}{l}\text { Unstandardized } \\
\text { Coefficients }\end{array}$} & \multirow{2}{*}{$\begin{array}{l}\text { Standardized } \\
\text { Coefficients } \\
\\
\text { Beta } \\
\end{array}$} & \multirow[b]{2}{*}{$\mathrm{t}$} & \multirow[b]{2}{*}{ SSig. } \\
\hline & $\mathrm{B}$ & Hata & & & \\
\hline $1 \quad$ (Constant) & 0,611 & 0,096 & & 354 & 000 \\
\hline Hayrettin Karaca & & & 0,629 & 5.188 & 000 \\
\hline
\end{tabular}

Bağımlı Değişken: TEMA'nın İmajı Beta:0,629

Tablo 4. Lider'in İmaj Üzerindeki Etkisini Gösteren Basit Doğrusal Regresyon Analizi Tabloları

Analiz sonuçlarına göre; Hayrettin Karaca'nın liderlik özellikleri ile TEMA Vakfı'nın imajı arasında pozitif $(0,566)$ bir ilişki vardır. Tabloda yer alan $t$ değeri bu ilişkinin istatistiksel olarak anlamlı olduğunu göstermektedir $(t=15,19, p=000)$. Liderlik ile imaj arasında istatistiksel açıdan anlamlı pozitif doğrusal bir ilişki vardır.

\section{Sonuç}

Vakıfların, toplum/devlet desteğini almaya ve olumlu imaj yaratabilmeye ihtiyaçları bulunmaktadır. İmaj ve liderlik birbirini etkileyen kavramlardır. Ancak ülkede liderle bütünleșen vakıf çok azdır. TEMA ve Hayrettin Karaca adeta birbirleriyle bütünleşmişlerdir ve birinden bahsedildiğinde akla hemen diğeri gelmektedir. Bu araștırmada kurucu lider olarak Hayrettin Karaca'nın TEMA Vakfı'nın imajı üzerindeki etkisi analiz edilmiștir.

Çalışmada, katılımcıların yarıya yakını $(\% 49,5)$ lisans ve üzeri eğitime sahip olmasına rağmen herhangi bir STK'ya üyelik konusunda, olumlu yanıt verenlerin toplamı sadece \%14,4'dür. Buna rağmen ankete katılanların büyük çoğunluğu TEMA Vakfı'nın varlığından $(\% 97,5)$ ve faaliyetlerinden $(\% 83,3)$ haberdardır. $\mathrm{Bu}$ ise TEMA'nın farkındalık yaratmak konusunda oldukça başarılı olduğunu göstermektedir. Katılımcıların \%60,8'inin TEMA'nın web sayfasını en az bir kere ziyaret etmiş olması, yapılan çalıșma için seçilen katılımcı profilinin uygun olduğunu göstermektedir.

TEMA Vakfı'nın imajı ile TEMA Vakfı lideri olarak Hayrettin Karaca'nın liderlik özellikleri arasında pozitif yönlü bir ilişki bulunmaktadır. Lider ile imaj arasında varlığı düşünülen bu ilişki korelasyon analiziyle ortaya konulmuștur ve bu ilişkinin varlığı regresyon analizinin gerçekleştirilebilmesi açısından önemli ve gereklidir.

Regresyon analizi sonuçlarına göre bir lider olarak Hayrettin Karaca, TEMA Vakfı'nın imajını olumlu yönde etkilemektedir. Bir kurum olarak vakıfların imajı, halkla ilişkiler faaliyetleri, farklı mecralardaki reklamlar, gerçekleştirilen projeler, çalışanlar, 
destekçiler gibi pek çok kriterden etkilenebilmektedir. Hayrettin Karaca'nın tek başına TEMA Vakfının imajı üzerinde $\% 39,6\left(R^{2}=0,396\right)$ oranında etkisinin olması son derece çarpıcıdır. Bunun nedeninin, bir lider olarak Hayrettin Karaca'nın vakfın faaliyetleri için maddi ve manevi olarak gösterdiği özverili ve etkileyici çalışmaları ve taşıdığı liderlik özellikleri olduğu söylenebilir.

Organik örgütler olarak da tanımlayabileceğimiz STK'ların "bilinir", "tanınır", "güvenilir", "sevilir" ve "etkinlikleri bilinir" olabilmesinde liderin payının çok yüksek olduğu bu araștırmayla da ortaya konulmuștur. Araștırmaya katılanların neredeyse tamamının TEMA'nın varlığından, \%83,3'ünün ise faaliyetlerinden haberdar olması da bunu göstermektedir. Çalışma sonuçlarına göre katılımcıların büyük çoğunluğu Hayrettin Karaca'yı genel olarak etkin ve başarılı bulmakta ve TEMA Vakfı ile özdeşleștirmektedir. Örneğin "Hayrettin Karaca TEMA Vakfı'nın lideridir" sorusuna katılımcıların sadece 11'i katılmadığını ifade etmiştir. Katılımcılardan 343 kişi Hayrettin Karaca'yı TEMA Vakfı'nın lideri olarak kabul etmektedir. Hayrettin Karaca'nın sahip olduğu kişilik ve liderlik özellikleri, TEMA Vakfı'nın imajını olumlu yönde etkilemiștir. Lideri ile bütünleșen ve lideri tanınıp bilinen vakıf ya da STK sayısının çok az olduğu düşünülürse Hayrettin Karaca'nın bu konudaki bașarısı TEMA Vakfı'na da olumlu yönde yansımıștır.

Sonuç olarak Hayrettin Karaca kurucu lider olarak TEMA Vakfi ile özdeșleșmiştir ve vakfın imajı üzerinde olumlu bir etkiye sahiptir. Hayrettin Karaca'nın başarılı bir lider olması TEMA Vakfı'nın da başarılı olmasına ve takipçileri tarafından benimsenmesine neden olmuştur. Elde edilen bu sonuç vakıf liderlerinin de en az kar amacı güden kurumların liderleri kadar önemli olduğunu göstermektedir. Hatta bu kurumların, genellikle takipçilerinin gönüllü olarak verdikleri maddi desteklerle faaliyetlerini sürdürebildikleri düşünülecek olursa, vakıflar için liderin daha da önemli olduğu ortaya çıkmaktadır. Bu nedenle vakıfların başarılı olabilmeleri ve takipçilerinin maddi manevi desteklerini alabilmeleri için etkin, güvenilir, özverili, özgüveni yüksek, fedakâr ve aktif liderle çalışmaları gerekmektedir.

Türkiye'de dernekler, birlikler, vakıflar da dâhil olmak üzere 111.498 STK (dernekler.gov.tr) olmasına rağmen bu çalışma yalnızca bir vakıf ile sınırlandırılmıştır. Ayrıca imajı etkileyen pek çok etmen arasından sadece liderliğin ele alınarak incelenmesi de başka bir sınırlılıktır.

Alanyazında, vakıfların imajının liderden etkilendiğini gösteren herhangi bir çalışmaya rastlanılmaması nedeniyle çalışmanın özgün olduğu ve alan yazına katkı sağlayabileceği düşünülmektedir.

Bulgular ışığında vakıfların takipçileri için de kar amacı güden işletmelerde olduğu gibi liderin önemli olduğu ortaya konulmuştur. Diğer vakıflara da imajlarını güçlendirebilmek için örgüt yöneticilerinden çok, bir lidere sahip olmaları önerilebilir.

Gelecek çalışmalarda aktif olarak faaliyet gösteren ve takipçisi TEMA'da olduğu gibi çok fazla sayıda olan diğer STK'larla da benzer bir çalışma gerçekleştirilip STK'lar arasında bir karşılaştırma yapılabilir. Ayrıca bu konuyla ilgilenen araştırmacılara, imajı etkileyen diğer kriterler arasında lider etkisinin tespit edilmesi önerilebilir.

$\mathrm{Bu}$ çalışma Hayrettin Karaca (1922-2020) hayattayken gerçekleștirilmiştir. Makalenin, hakem süreci devam ederken ne yazık ki aramızdan ayrılmıştır. Kendisini rahmetle anıyoruz. Ülkemize yaptığı değerli katkıları unutulmayacaktır.

\section{KAYNAKÇA}

BAKAN, Ö. (2005). Kurumsal imaj. Konya: Tablet Kitabevi.

BALLEN, K. (1992). America's Most Admired Corporations. Fortune, 125 (3), 30-

34. 
BASS, B. M. ve STOGDİLL, R. M. (1981). Bass\&Stogdill's handbook of leadership. London: The Free Press, A Division of Macmillian Inc.

BEGEÇ, S. (1999). Modern liderlik yaklaşımları ve uygulamaları. Yayınlanmamış yüksek lisans tezi, Gebze Yüksek Teknoloji Enstitüsü, Gebze.

BENOIT, W. L. (1997). Image Repair Discourse and Crisis Communication. Public Relations Review, 23 (2), 177-186.

BROMLEY, D. B. (1993). Reputation, image and impression management. England: John Willey 8 Sons Ltd. Yayıncilık.

ÇAHA, Ö. (2000). Aşkın devletten sivil topluma. İstanbul: Gendaş Kültür Sanat

ÇETIN, C. (2008). Yöneticilerin liderlik stilleri, değişim yönetimi ve ekip çalışması arasındaki ilişkilerin çok yönlü olarak değerlendirilmesi. İstanbul: İstanbul Ticaret Odası Yayınları, Yayın No. 2008-15.

ÇETIN, M. (2013) Sivil Toplum Kuruluşlarında Liderin Başarıya Etkisi ve Kurumsallaşma, (http://www.sistems.org/stklarda_liderlik.htm)

DOĞANLI, B. (2015). STK (Vakıflar) ve Marka İmajı. Dumlupınar Üniversitesi Sosyal Bilimler Dergisi, ss.47-59.

EKICİ, K.M. (2006). Vizyoner liderlik. Ankara: Turhan Kitabevi Yayınları.

GUPTA, S. (2002). Strategic dimensions of corporate image: corporate ability and corporate social responsibility as sources of competitive advantage via differentiation uni. dissertations. Temple University.

GÜLEÇ, Ș. N. (2014). Kurumsal imaj. Samsun: On Dokuz Mayıs Üniversitesi Uzaktan Eğitim Merkezi.

GÜLTEKINN, N. ve KÜÇÜK, F. (2004). Kurum İmajı Açısından Paydaş Memnuniyeti, Marmara Üniversitesi İ.I.B.F Dergisi, Cilt: XIX, 1. Yayınları.

HABERMAS, J. (2015). Kamusallı̆̆ın yapısal dönüşümü. İstanbul: İletişim

İSLAMOĞLU, A. H. (2011). Sosyal bilimlerde araștırma yöntemleri : (SPSS uygulamalı). İstanbul: Beta Basım Yayın.

İSLAMOĞLU, A.H. ve ALNIAÇIK, Ü. (2014). Sosyal bilimlerde araștırma yöntemleri : (SPSS uygulamalı), İstanbul: Beta. Yayınları.

KADIBEŞEGIL, S. (1999). Halkla ilişskilere nereden başlamalı?. Ankara: Media Cat

KİLIK, M. (2011). Kurum imajı ve lider etkileşimi: sivil toplum kuruluşları örneği,

İstanbul Kültür Üniversitesi. Sosyal Bilimler Enstitüsü Yüksek lisans tezi Yayınları.

KARASAR, N. (2009). Bilimsel araştırma yöntemi. (19th Ed.), Ankara: Nobel

KOÇEL, T. (2003). İşletme yöneticiliği. İstanbul: Beta Yayınları.

LIN, N. (1976). Foundations of social research. Usa: Mcgraw-Hill.

MARANGOZ, M. \& BİBER, L. (2007). Kurumsal İmajın ve Kurumsal Ünün Müşteri

Bağlılığına Etkileri. KMÜ İktisadi ve İdari Bilimler Fakültesi Dergisi, Aralık Sayısı.

MITCHELL, G. E. (2015), The Attributes Of Effective Ngos And The Leadership

Values Associated With A Reputation For Organizational Effectiveness. Nonprofit

Management and Leadership, 26(1), 39-57.

MUFTI, M., XIAOBAO, P., SHAH, S. J., SARWAR, A., \& ZHENQING, Y. (2019),

Influence of Leadership Style on Job Satisfaction of NGO Employee: The Mediating Role of Psychological Empowerment. Journal of Public Affairs, e1983.

MWAI, G., NAMADA, J. \& KATUSE, P. (2018), Does Leadership Style Influence

Organizational Effectiveness in Non-Governmental Organizations?, International Journal of Business and Management; 13 (8).

OKAY, A. (1999). Kurum kimliği. 2. Baskı, Ankara: Mediacat Yayınları. 
Ayla Topuz Savaș, Bahar Suvacı, "Vakıfların Kurumsal İmajı Üzerinde Lider Etkisi: TEMA Vakfı ve Hayrettin Karaca”, İstanbul Gelişim Üniversitesi Sosyal Bilimler Dergisi, 8 (1), Nisan 2021, ss. 93-110.

ÖZAYDIN, M. (2003). Vakıfların sosyal politika işlevleri ve günümüzde artan önemi. Ankara: Kamu- İș, 7 (2).

ÖZMUTAF, N. ve KAYALAR, M. (2008). Sivil Toplum Kuruluşlarında Gelecek Yönelimli Lider Performans Profili: İstatiksel Bir Yaklaşım. Ege Akademik Bakış, 8(2), 563-585.

ÖZTÜRK, C. M. ve ŞARDAĞI E., (2018). Kurumsal Kimlik Aracı Olarak Facebook: Türkiye'deki Sivil Toplum Kuruluşları (STK) Üzerine Bir Değerlendirme. Galatasaray Üniversitesi İleti-ş-im Dergisi, 28, 115-141. DOI: 10.16878/gsuilet.436034

PELTEKOĞLU, F. B. (2014). Halkla ilişkiler nedir? 8. Baskı, İstanbul: Beta Yayınları.

PELTEKOĞLU, F. B. (1997). Kurumsal İletişim Sürecinde İmajın Yeri. İstanbul Üniversitesi İletişim Fakültesi Dergisi, (4), 125-145.

SARAÇOĞLU, N. T. (2013). İsletmelerde kurumsal sosyal sorumluluk uygulamalarının müşteri güveni, müşteri bağlılığı ve firma imajı üzerindeki etkileri: otel ișletmelerinde bir uygulama. Yayınlanmamıș yüksek lisans tezi, Adnan Menderes Üniversitesi Sosyal Bilimler Enstitüsü, İşletme Anabilim Dalı.

SEZIKK, M. (2019). Türkiye'de sivil toplum kuruluşlarının ișlevleri ve sorun alanları. Research Studies Anatolia Journal, 2, (4), 118-125.

SCHUKIES, G. (1998). Halkla ilişkilerde müşteri memnuniyetine dönük kalite. (Çev. Ahmet Ünver), Altın Kitap Serisi, No:1, İstanbul: Rota Yayınları.

SCHWAIGER, M. (2004). Components and parameters of corporate reputation: an emprical study. Schmalenbach Business Review, (56), 46-71.

TAȘKIN, E. \& DÖNMEZ, S. (2005). Kurumsal imaj oluşturmada halkla ilişkilerin rolü ve bir alan araștırması. Akademik Bakış Uluslararası Sosyal Bilimler E-Dergisi, (7).

TOSUN, N. B. (2003). Pazarlama halkla ilişkileri ve reklam: bütünleşik pazarlama iletişimi yönlü bir yaklaşım. İstanbul: Türkmen Kitabevi.

TOLUNGÜÇ, A. (2000). Turizmde tanıtım ve reklam. Ankara: Mediacat Kitapları. yayıncılık.

TUNA, M. ve TUNA, A.A. (2007). Kurumsal kimlik yönetimi. Ankara: Detay

TUTAR, Ö. (2007). Türkiye'nin kamu istihdam kurumu olarak Türkiye iş kurumunun toplumdaki imaj tespiti ve imaj geliştirme üzerine bir çalışma. Uzmanlık Tezi, Ankara: Çalıșma ve Sosyal Güvenlik Bakanlığı Türkiye İș Kurumu Genel Müdürlüğü

http://www.tdk.gov.tr/index.php?option=com gts\&arama=gts\&kelime=sivil $\% 2$ 0toplum\&guid=TDK.GTS.52c5bbf7567e36.53450971 (20.8.2018).

http://www.tema.org.tr/web_14966-2_1/neuralnetwork.aspx?type=138\#( 21.08.2018).

http://arsiv.dha.com.tr/hayrettin-Karaca-alternatif-nobel-olarak-bilinen-dogruyasam-odullerinden-buyuk-cevre-odulunu-kazandi-son-dakika-haberi_368559.html (21.08.2018).

https://www.youtube.com/watch?v=KjE2nm3H_bc (21.08.2018).

https://www.youtube.com/watch?v=lYDDNE-QBiw (21.08.2018).

http://www.biyografi.info/kisi/hayrettin-Karaca (23.08.2018).

http://www.tema.web.tr/web_14966-2_1/neuralnetwork.aspx?type=22

(21.08.2018).

http://www.tema.web.tr/web 14966-

2_1/entitialfocus.aspx?primary $\_$id=247\&type=23\&target=categorial $1 \&$ detail=single $\& s p$ table $=\&$ sp primary $=\&$ sp table extra $=\& o p e n f r o m=$ sortial $(21-08-2018)$.

http://www.tema.web.tr/web_14966-2_1/neuralnetwork.aspx?type=55)

(21.08.2018).

http://www.elektrikport.com/universite/iyi-bir-liderde-gorebileceginiz-11ozellik-nelerdir/12144\#ad-image-0 (21.08.2018). 
Ayla Topuz Savaș, Bahar Suvacı, "Vakıfların Kurumsal İmajı Üzerinde Lider Etkisi: TEMA Vakfı ve Hayrettin Karaca”, İstanbul Gelişim Üniversitesi Sosyal Bilimler Dergisi, 8 (1), Nisan 2021, ss. 93-110.

http://www.biyografi.net/kisiayrinti.asp?kisiid=659 (23.08.2018).

http://www.tema.org.tr (29.09.2018).

https://yoldanciktim.com/arboretum-nedir/(05.10.2018).

https://www.biyolojigunlugu.com/tema-vakfi-kurucusu-onursal-baskani-

hayrettin-Karaca-kendi-cikari-icin-beni-ac-birakanlar-var/ (10.10.2018).

https://www.dernekler.gov.tr/tr/Teskilat/tanitim.aspx (27.10.2018).

https://www.tbmm.gov.tr/kanunlar/k4721.html (22.08.2018).

\section{Summary}

Today, individuals, societies, corporation, non-profit organizations (NPO) and even countries see the concept of image as an integral part of their values/assets. Image can facilitate competition and support from the target group. The sustainability of foundations as a NPO depends on the support they receive. One of the elements necessary for the establishment a strong image of foundations is the leader. In other words, it is important that foundations have a strong leader and a strong corporate image in order to be sustainable. However, no study has been found in the literature that measures the corporate image of foundations or analyzes the effect of the leader on the corporate image of the foundation.

The aim of this study is to determine the effect of the leader on having a strong foundation image. For this purpose, the effect of Hayrettin Karacan as the founding leader on the image of TEMA Foundation was tried to be measured. In this study, general survey model approach was used and data were collected through descriptive research method and survey technique. In this study, easy sampling method was used. Facebook users had access to the survey by giving a survey link from their Facebook accounts. The survey has been answered by 354 Facebook users. These research findings cannot be generalized to all facebook users and the general public, they can only be guiding for similar target groups.

The scale includes 23 questions to measure TEMA's image and 20 questions to determine Hayrettin Karaca's leadership characteristics. Reliability analyzes were conducted for the questions in the survey. According to the reliability analysis, Cronbach's Alpha value was $\alpha: 0.912$ for the leadership scale and $\alpha: 0.924$ for the TEMA Foundation Image scale.

According to the results of the research, gender ratios of the participants were very close to equal distribution (54.5\% female, $44.5 \%$ male). Most of the participants were single (70.3\%), and the majority were between 17-24 years (44.9\%). Most of the participants (46.3\%) were high school graduates. Nearly half of them have undergraduate and graduate education (49.5\%). Among the participants, the number of participants (14.4\%) who are members of any NPO is very low. The majority of the participants (73.7\%) did not participate in any NPO activities. Nevertheless, the majority of the respondents (97.5\%) were aware of the existence and activities of the TEMA Foundation (83.3\%). $60.8 \%$ of the participants visited TEMA's website.

In the second part of the study, in order to determine the relationship between leader and image, correlation analysis (using Pearson test) was performed. The correlation coefficient was 0.629 and the significance level (Sig.) was 0.000. There is a positive relationship between TEMA's image and Hayrettin Karaca's leadership.

Regression Analysis was conducted in order to measure the effect of Hayrettin Karaca's leadership on TEMA's image. As a result of the analysis of the regression model, the model was found to be statistically significant ( $F=230.663, p=0.00)$.

As a result, Hayrettin Karaca is identified as a founding leader of TEMA and has a positive impact on the image of the foundation. Hayrettin Karaca's success as a leader led 
TEMA to be successful and adopted by his followers. This result shows that NPO and foundation leaders are at least as important as the leaders of corporations. This is even more important for leading NPOs and foundations, as they are often able to carry out their activities voluntarily with the financial support of their followers. For this reason, NPOs and foundations need to work with effective, reliable, self-sacrificing, self-confident, altruistic and active leaders in order to be successful and to receive financial support from their followers.

In the light of the findings, it was revealed that the leader is also important for the followers of foundations as in profit-making corporations. The fact that 343 of the participants accepted Hayrettin Karaca as the leader of TEMA. Other foundations may also be advised to have a leader rather than organization managers to strengthen their image.

In future studies, a similar study can be carried out with other NPOs that are active and have a large number of followers as in TEMA, and a comparison can be made between them. 